\title{
Laporan Kasus Berbasis Bukti Pengaruh Susu yang Mengandung Sinbiotik Terhadap Tumbuh Kembang Anak Balita
}

\author{
Ratih Puspita, Pramita G. Dwipoerwantoro \\ Departemen Ilmu Kesehatan Anak Fakultas Kedokteran Universitas Indonesia/RS. Dr. Cipto Mangunkusumo, Jakarta
}

\begin{abstract}
Latar belakang. Saat ini semakin banyak susu dengan suplementasi sinbiotik. Beberapa studi menunjukkan bahwa sinbiotik dapat meningkatkan pertumbuhan dan menurunkan morbiditas penyakit infeksi pada anak.

Tujuan. Mengetahui pengaruh susu yang mengandung sinbiotik terhadap tumbuh kembang anak berusia di bawah lima tahun.

Metode. Penelusuran pustaka database elektronik: PubMed, Cochrane, Highwire.

Hasil. Didapatkan empat studi acak terkontrol yang relevan. Studi pertama menunjukkan kenaikan berat badan pada kelompok sinbiotik yang lebih tinggi ( $\mathrm{p}=0,025)$, tetapi tidak terdapat perbedaan yang bermakna dalam hal kenaikan tinggi badan dan lingkar kepala, frekuensi dan karakteristik tinja, titer antibodi, serta perkembangan. Studi kedua menunjukkan pada kelompok intervensi terdapat peningkatan kadar IgA total lebih tinggi ( $\mathrm{p}<0,01)$, efek positif pada berat badan dan tinggi badan, serta angka kejadian infeksi yang cenderung lebih rendah. Studi berikutnya menunjukkan rerata kecepatan kenaikan berat badan pada kelompok intervensi 0,13 $\mathrm{kg} /$ tahun lebih tinggi $(\mathrm{p}=0,02)$ dan pada analisis multivariat tampak kelompok intervensi mengalami kenaikan berat badan yang lebih tinggi (IK95\% 0,006-0,21; p=0,04). Studi terakhir menunjukkan angka kejadian diare, disentri, pneumonia, penyakit berat, infeksi telinga, serta penggunaan antibiotik yang lebih rendah pada kelompok intervensi.

Kesimpulan. Susu yang mengandung sinbiotik memilik kecenderungan efek positif terhadap pertumbuhan dan cenderung menurunkan morbiditas penyakit infeksi pada balita sehat, serta tidak menyebabkan reaksi simpang. Sari Pediatri 2016;18(2):164-8
\end{abstract}

Kata kunci: susu balita, sinbiotik, tumbung kembang

\section{Effect of Growing-up Milk Containing Synbiotics on Toddlers' Growth and Development}

Ratih Puspita, Pramita G. Dwipoerwantoro

Background. Growing-up milk containing synbiotics has been commonly produced nowadays. Some studies showed that synbiotics may improve growth and decrease morbidity of infectious diseases in children, but these studies were mostly done in babies.

Objects. To study the effect of growing-up milk containing synbiotics on growth and development in toddlers.

Methods. Literature research using the electronic database: PubMed, Cochrane, Highwire.

Results. Four relevant randomized controlled trial study was found. The first study found a higher body weight increment in the study group ( $\mathrm{p}=0.025)$, but no significant difference in body height and head circumference increment, defecation, antibody titer, and child's development. The second study found that in the study group there was a higher IgA level increment $(\mathrm{p}<0.01)$, positive effects on weight and height, and also lower incidence of infection. The next study found that the weight increment speed was $0,13 \mathrm{~kg} / \mathrm{year}$ higher in the intervention group $(\mathrm{p}=0.02)$ and on multivariate analysis it is showed that the intervention group had a higher weight increment $(95 \%$ CI $0.006-0.21 ; \mathrm{p}=0.04)$. The last study show a lower incidence of diarrhea, dysentri, pneumonia, severe illness, ear discharge, and antibiotic usein the intervention group.

Conclusion. Synbiotic-containing-milk has positive effects on growth and also reduces morbidity in healthy toddlers, without significant adverse reactions. Sari Pediatri 2016;18(2):164-8

Keywords: growing-up milk, synbiotic, growth and development Alamat korespondensi: Dr. Ratih Puspita. DR. Dr Pramita G. Dwipoerwantoro, SpA(K). Departemen Ilmu Kesehatan Anak Fakultas Kedokteran
Universitas Indonesia/RS. Dr. Cipto Mangunkusumo, Jakarta.. Email: a.ratih.puspita@gmail.com 
Ratih Puspita dkk: Pengaruh susu yang mengandung sinbiotik terhadap tumbuh kembang anak balita

M anfaat probiotik pada anak sudah banyak dipelajari. Efek yang sudah terbukti, antara lain, mengatasi diare akut akibat infeksi virus serta mencegah diare yang terkait antibiotik. Probiotik juga dikatakan dapat memperbaiki pola defekasi, mencegah penyakit infeksi dan alergi/atopi pada anak, menurunkan morbiditas akibat infeksi, serta mengatasi gastritis akibat infeksi Helicobacter pylori, irritable bowel syndrome, dan kolik infantil. ${ }^{1-3} \mathrm{Uji}$ klinis acak mengenai manfaat prebiotik pada anak masih terbatas, tetapi prebiotik diperkirakan memiliki efek jangka panjang dalam mencegah dermatitis atopik dan penyakit infeksi pada anak sehat, mencegah diare dan konstipasi, mencegah kanker, serta menstimulasi penyerapan mineral. ${ }^{1,2}$

Berdasarkan fakta mengenai manfaat probiotik dan prebiotik, saat ini semakin banyak susu formula bayi maupun susu balita yang disuplementasi dengan sinbiotik (gabungan probiotik dengan prebiotik). Beberapa studi menunjukkan bahwa konsumsi susu formula atau produk lain yang mengandung sinbiotik dapat meningkatkan pertumbuhan dan menurunkan morbiditas pada bayi dan balita. ${ }^{4-6}$ Namun, beberapa studi tersebut meneliti manfaat susu formula dengan sinbiotik terhadap bayi. Berdasarkan hal tersebut maka diajukan pertanyaan klinis sebagai berikut: Pada balita sehat, apakah pemberian susu yang mengandung sinbiotik menghasilkan pertumbuhan dan perkembangan yang lebih baik dibandingkan dengan susu yang tidak mengandung sinbiotik?

\section{Kasus}

Seorang anak lelaki sehat berusia 2 tahun 11 bulan memiliki berat badan $18 \mathrm{~kg}$ dan tinggi badan 102 $\mathrm{cm}$. Anak ini tidak memiliki masalah buang air besar, tidak memiliki riwayat alergi susu sapi dan saat ini mengonsumsi produk susu untuk usia 1-3 tahun tanpa suplementasi probiotik dan/atau prebiotik. Data antropometri 3 bulan yang lalu adalah sebagai berikut, BB $17 \mathrm{~kg}$ dan TB $100 \mathrm{~cm}$. Orangtua pasien menanyakan mengenai jenis susu yang dapat meningkatkan kenaikan berat badan anaknya. Sejak kunjungan saat itu anak diberikan susu yang mengandung sinbiotik sebanyak $3 \times 210 \mathrm{~mL}$ per hari selama satu bulan, kemudian diukur kembali berat dan tinggi badannya. Hasil pengukuran menunjukkan BB
19,8 $\mathrm{kg}$ dan TB $103 \mathrm{~cm}$. Selama mengonsumsi susu tersebut tidak terdapat perubahan konsistensi feses maupun efek samping lainnya.

Sebagai pembanding seorang anak balita lain yang mengonsumsi susu tanpa sinbiotik dengan jumlah yang sama juga diamati perubahan berat dan tinggi badannya pada titik-titik yang sesuai dengan anak pada kasus. Pada bulan ke-0 (usia 2 tahun 10 bulan) anak ini memiliki BB $14 \mathrm{~kg}$ (pada titik median) dan TB 94,3 $\mathrm{cm}$ (antara -1SD sampai median). Selanjutnya, pada bulan ke-3 (usia 3 tahun 1 bulan) anak ini memiliki BB $14,5 \mathrm{~kg}$ (pada titik median) dan TB 94,5 cm (antara -1SD sampai median).

Berdasarkan data dari dua balita yang diamati, saat keduanya mengonsumsi susu tanpa sinbiotik tampak kenaikan berat dan tinggi badannya konsisten pada kolom grafik yang sama. Akan tetapi, pada balita pertama yang mendapat intervensi berupa pemberian susu yang mengandung sinbiotik, setelah konsumsi susu tersebut selama satu bulan tampak terjadi pergeseran berat badan pada kurva $\mathrm{WHO}$, yaitu dari antara $1 \mathrm{SD}$ sampai $2 \mathrm{SD}$ menjadi antara $2 \mathrm{SD}$ sampai $3 \mathrm{SD}$.

\section{Metode penelusuran literatur}

Prosedur pencarian literatur untuk menjawab masalah di atas adalah dengan menelusuri pustaka secara online dengan menggunakan database elektronik PubMed, Highwire dan Cochrane dengan kata kunci: "synbiotic", "milk", "AND" "growth". Kriteria inklusi artikel adalah artikel hasil uji klinis acak terkontrol atau hasil metaanalisis dengan batasan studi dilakukan pada manusia dan bahasa pengantar adalah bahasa Inggris. Terdapat empat artikel yang terpilih dan kemudian menjalani telaah kritis untuk menentukan apakah artikel tersebut sahih, penting dan dapat diterapkan pada pasien. Level of evidence ditentukan berdasarkan klasifikasi yang dikeluarkan oleh Oxford Centre for Evidence-based Medicine.

\section{Hasil penelusuran literatur}

1. Uji klinis acak tersamar ganda (randomized controle trial) (level of evidence II)

Penelitian dilakukan di Jakarta oleh Firmansyah $\mathrm{dkk}^{7}$ mengenai pengaruh susu yang mengandung sinbiotik terhadap pertumbuhan balita sehat berusia 12 bulan. Penelitian ini menggunakan 
susu yang mengandung Bifidobacterium longum BL999 dan Lactobacillus rhamnosus LPR sebagai probiotik, inulin dan fructo-oligosaccharide sebagai prebiotik, serta long chain polyunsaturated fatty acids (LCPUFA). Analisis dilakukan terhadap 290 anak yang mengonsumsi susu $2 \times 200 \mathrm{~mL}$ per hari selama 4 bulan. Kenaikan berat badan rata-rata dari usia 12 bulan sampai usia 16 bulan pada kelompok sinbiotik didapatkan lebih tinggi dibandingkan dengan kelompok kontrol $(\mathrm{p}=0,025)$. Pada usia 16 bulan anak pada kelompok sinbiotik memiliki berat badan yang lebih besar dibandingkan dengan kelompok kontrol $(9711 \pm 1142 \mathrm{~g}$ vs. $9643 \pm 1218 \mathrm{~g}$ ). Dalam hal kenaikan tinggi badan dan lingkar kepala tidak ditemukan perbedaan yang bermakna antara dua kelompok tersebut. Selain itu, ditemukan pula bahwa tidak terdapat perbedaan yang bermakna dalam hal respon imun (diwakili dengan peningkatan titer antibodi campak dan hepatitis A pasca pemberian vaksin), karakteristik feses, serta perkembangan motorik dan kognitif antara dua kelompok pada penelitian ini.

2. Uji klinis acak berkelompok tersamar ganda (randomized controle trial) (level of evidence II) Studi dilakukan di Vietnam oleh Xuan dkk. ${ }^{8}$ Penelitian yang mengambil sampel anak berusia 18 sampai 36 bulan ini merupakan studi uji klinis acak berkelompok tersamar ganda. Intervensi dilakukan selama lima bulan dengan memberikan susu sebanyak $2 \times 180 \mathrm{~mL}$ per hari, 5 hari seminggu. Kelompok intervensi mendapatkan susu yang mengandung jumlah kalori dan protein yang serupa dengan kelompok kontrol, tetapi mengandung sinbiotik (L. paracasei NCC2461 dan B. longum NCC3001; inulin dan FOS) dan difortifikasi dengan vitamin (A, C, E), mineral (zinc dan selenium), serta docosahexaenoic acid (DHA). Setelah 5 bulan, tampak peningkatan kadar IgA total yang bermakna secara statistik pada kelompok intervensi $(\mathrm{p}<0,01)$. Dalam hal pertumbuhan didapatkan efek positif pada berat badan dan tinggi badan yang sudah tampak pada bulan ke-2, tetapi baru bermakna secara statistik pada evaluasi di bulan ke-5. Angka kejadian infeksi yaitu infeksi saluran napas atas dan diare pada kelompok intervensi cenderung lebih sedikit dibandingkan dengan kelompok kontrol meski perbedaan ini tidak bermakna secara statisik.
3. Uji acak terkontrol (randomized controle trial) ( level of evidence II)

Studi oleh Sazawal dkk ${ }^{9}$ di New Delhi, India, dengan jumlah 600 sampel berusia 1-3 tahun. Intervensi dilakukan selama satu tahun berupa pemberian susu setiap hari sebanyak 3 sachet per hari. Kelompok intervensi mendapatkan susu yang mengandung probiotik B lactis HN019 sebanyak $1,9 \times 10^{7} \mathrm{cfu} /$ hari dan $2,4 \mathrm{~g}$ oligosakarida sebagai prebiotik. Hasil penelitian ini menunjukkan bahwa rerata kecepatan kenaikan berat badan pada kelompok intervensi $0,13 \mathrm{~kg} /$ tahun lebih tinggi dibandingkan dengan kelompok kontrol $(\mathrm{p}=0,02)$. Pada analisis multivariat dengan menyesuaikan faktor usia, jenis kelamin, status sosio-ekonomi, dan status anemia, kelompok intervensi mengalami kenaikan berat badan yang lebih tinggi secara signifikan ( $95 \%$ CI 0,006-0,21; $\mathrm{p}=0,04)$ dibandingkan dengan kelompok kontrol.

4. Studi kohort (individual cohort study) (level of evidence III)

Studi lain dari Sazawal dengan menggunakan sampel yang sama dengan studi di New Delhi meneliti pengaruh pemberian intervensi terhadap penyakit umum pada anak, yaitu diare, pneumonia, dan demam. ${ }^{10}$ Secara umum, angka kejadian diare pada kelompok intervensi ternyata 6\% lebih rendah $(\mathrm{p}=0,08)$, tetapi pengelompokan berdasarkan usia menunjukkan bahwa pada kelompok usia 12-24 bulan perbedaan angka kejadian diare tidak bermakna secara statistik [1\%lebih rendah, $\mathrm{p}=0,91$ ], sedangkan pada kelompok usia $>24$ bulan perbedaannya bermakna $[10 \%$ lebih rendah, $\mathrm{p}=0.02]$. Insiden disentri $21 \%$ lebih rendah pada kelompok intervensi $(\mathrm{p}=0,05)$. Penurunan insidens pneumonia juga ditemukan pada kelompok intervensi, yaitu 24\% (95\% CI: 0 sampai $42 \%$ ) dan $35 \%$ penurunan angka pneumonia berat $(95 \% \mathrm{CI}: 0$ sampai 58\%), tetapi angka ini memiliki interval kepercayaan yang terlalu lebar. Kelompok intervensi mengalami angka kejadian penyakit berat $16 \%$ lebih rendah $(\mathrm{p}=0,004)$, durasi demam tinggi yang 5\% lebih singkat (bermakna secara statistik), dan keluhan sekret telinga yang 7\% lebih rendah. Penggunaan antibiotik juga lebih rendah pada kelompok intervensi $[6 \%$ (95\% CI: 3 sampai 9\%), $\mathrm{p}=0,001]$. 


\section{Pembahasan}

Jumlah studi yang mempelajari pengaruh susu yang mengandung sinbiotik terhadap tumbuh kembang balita masih sangat terbatas, yaitu hanya terdapat beberapa uji acak terkontrol dan belum terdapat meta analisis. Studi yang ada saat ini semuanya menunjukkan adanya efek positif terhadap pertumbuhan, khususnya berat badan. ${ }^{7-9}$ Pengaruh terhadap tinggi badan hanya ditemukan pada satu studi, kemungkinan karena durasi pengamatan yang relatif singkat untuk mendapatkan perbedaan kenaikan tinggi badan yang bermakna. $^{8}$

Hanya terdapat satu studi yang mengamati efek sinbiotik terhadap perkembangan, yaitu studi yang dilakukan oleh Firmansyah dkk. ${ }^{7}$ Pada penelitian tersebut tidak ditemukan perbedaan yang bermakna pada perkembangan perkembangan motorik maupun mental. Kesimpulan yang sahih belum dapat diambil karena durasi pengamatan belum cukup lama dan jumlah sampel relatif sedikit.

Probiotik bermanfaat terhadap kesehatan terutama karena kemampuannya untuk memodulasi sistem imun. ${ }^{1,2}$ Imunitas yang baik merupakan faktor penting yang mendukung pertumbuhan dan perkembangan optimal. Oleh karena itu, beberapa studi mengamati juga pengaruh konsumsi susu sinbiotik terhadap imunitas. Salah studi mengambil parameter respon pembentukan antibodi terhadap vaksin untuk menggambarkan imunitas, sedangkan studi lain menggunakan parameter IgA total untuk melihat adanya peningkatan fungsi imun. ${ }^{7,8}$ Pada dua studi ini hasilnya tidak secara konsisten menunjukkan pengaruh positif sinbiotik terhadap sistem imun. Sesungguhnya, tidak ada satu parameter pun yang benar-benar menggambarkan fungsi imun. Kemungkinan karena alasan inilah studi yang lain memilih pendekatan yang lebih aplikatif yaitu mengamati angka kejadian morbiditas beberapa penyakit yang umum terjadi pada balita. ${ }^{8,10}$ Secara umum, studi-studi ini menunjukkan adanya peningkatan imunitas dengan konsumsi sinbiotik, tetapi perlu diingat bahwa terdapat banyak faktor lain yang dapat menyebabkan bias, misalnya higiene serta paparan terhadap penyakit. Selain itu, jumlah studi yang masih sangat terbatas ini belum cukup untuk membuat kesimpulan mengenai pengaruh sinbiotik terhadap imunitas.

Semua penelitian yang dikaji pada tulisan ini menggunakan Lactobacillus dan Bifidobacteria sebagai probiotik, meskipun terdapat perbedaan spesies pada setiap penelitian. Prebiotik yang digunakan pada penelitian Firmansyah $\mathrm{dkk}^{7}$ dan Ninh $\mathrm{dkk}^{8}$ adalah inulin dan fruktooligosakarida, sedangkan dua penelitian lainnya hanya menuliskan oligosakarida dalam kandungan susu yang diuji. Memang Lactobacillus dan Bifidobacteria merupakan dua bakteri utama yang paling banyak digunakan sebagai probiotik dan beberapa penelitian telah menunjukkan manfaatnya terhadap kesehatan misalnya dalam mengurangi angka diare dan infeksi saluran cerna., ${ }^{2,4}$

Seluruh studi yang dikaji menunjukkan keamanan konsumsi sinbiotik serta efek samping yang minimal atau ringan. Hal ini sesuai dengan hasil penelitian yang sudah ada sebelumnya mengenai keamanan sinbiotik pada bayi dan anak. ${ }^{2}$

Kekurangan pada penelitian ini adalah banyaknya hal lain di luar konsumsi susu yang dapat memengaruhi pertumbuhan dan perkembangan, misalnya asupan diet, stimulasi, serta potensi genetik. Semua faktor tersebut dapat menjadi faktor perancu dalam studistudi mengenai pengaruh sinbiotik. Untuk dapat mengambil simpulan bahwa susu yang mengadung sinbiotik memang meningkatkan pertumbuhan, semua faktor perancu tersebut harus dikontrol misalnya dengan mengikutsertakan data analisis diet dan pengamatan stimulasi yang diberikan kepada sampel untuk kemudian dinilai kesetaraannya antara dua lengan penelitian (lengan intervensi dan lengan kontrol). Selain faktor di luar susu, di dalam susu yang dipelajari pun terdapat komposisi selain sinbiotik yang juga memengaruhi pertumbuhan, misalnya LCPUFA, AA, DHA, vitamin, dan mineral. Dengan adanya faktor perancu tersebut apabila ditemukan pengaruh positif pada pertumbuhan, belum tentu peningkatan pertumbuhan tersebut semata-mata disebabkan oleh sinbiotik yang terkadung di dalam susu yang diuji.

\section{Kesimpulan}

Berdasarkan bukti ilmiah yang telah dipaparkan di atas dapat disimpulkan bahwa susu yang mengandung sinbiotik memilik efek positif terhadap pertumbuhan dan cenderung menurunkan morbiditas pada balita sehat. Selain itu, susu dengan sinbiotik tidak menyebabkan reaksi simpang. Dengan pertimbangan kecenderungan pengaruh positif terhadap pertumbuhan dan imunitas serta efek samping yang minimal, 
maka pemberian susu yang mengandung sinbiotik dapat dipertimbangkan pada balita untuk menunjang tumbuh kembang optimal.

\section{Saran}

Masih dibutuhkan lebih banyak penelitian yang membuktikan pengaruh susu yang mengandung sinbiotik terhadap pertumbuhan dan perkembangan anak. Diharapkan penelitian terkait manfaat susu yang mengandung sinbiotik terhadap tumbuh kembang anak dapat mempertimbangkan faktor perancu terutama efek diet selain susu yang mengandung probiotik/prebiotik/sinbiotik.

\section{Daftar pustaka}

1. de Vrese M, Schrezenmeir J. Probiotics, prebiotics, and synbiotics. Adv Biochem Eng Biotechnol 2008;111:1-66.

2. Thomas DW, Greer FR. Probiotics and prebiotics in pediatrics. Pediatrics 2010;126:1217-31.

3. Marteau PR dVM, Cellier CJ, Schrezenmeir J. Protection from gastrointestinal diseases with the use of probiotics. Am J Clin Nutr 2001;73:430S-6S.

4. Vendt N GH, Tuure T, Malminiemi O, Wuolijoki E, Tillmann V, Sepp E, Korpela R. Growth during the first 6 months of life in infants using formula enriched with lactobacillus rhamnosus gg: Double-blind, randomized trial. J Hum Nutr Diet 2006;19:51-8.

5. Saran S, Gopalan S, Krishna TP. Use of fermented foods to combat stunting and failure to thrive. Nutrition 2002;18:393-6.

6. Nopchinda S, Varavithya W, Phuapradit P. Effect of bifidobacterium BB12 with or without streptococcus thermophilus supplemented formula on nutritional status. J Med Assoc Thai 2002;85:S1225-31.

7. Firmansyah A, Dwipoerwantoro PG, Kadim M, Alatas S, Conus N, Lestarina L, dkk. Improved growth of toddlers fed a milk containing synbiotics. Asia Pac J Clin Nutr 2011;20:69-76.

8. Ninh Xuan NN, Wang D, Grathwohl D, Lan PNT, Kim HVT,Goyer A, dkk. Effect of a growing-up milk containing synbiotics on immune function and growth in children: A cluster randomized, multicenter, doubleblind, placebo controlled study. Clin Med Insights Pediatr 2013;7:49-56.

9. Sazawal S, Dhingra U, Hiremath G, Sarkar A, Dhingra P, Dutta A, dkk. Effects of bifidobacterium lactis HN019 and prebiotic oligosaccharide added to milk on iron status, anemia, and growth among children 1 to 4 years old. J Pediatr Gastroenterol Nutr 2010;51:341-6.

10. Sazawal S, Dhingra U, Hiremath G, Sarkar A, Dhingra P, Dutta A, dkk. Prebiotic and probiotic fortified milk in prevention of morbidities among children: Community-based, randomized, double-blind, controlled trial. PLoS ONE 2010;5:1-8. 